\title{
Cyanogenic Potentials of Garri Flour: Implications on the academic performance of Junior Secondary School Students.
}

\author{
Dr. Wisdom J. Owo \\ Department of Integrated Science, Faculty of Natural and Applied Sciences, \\ Ignatius Ajuru University of Education Rumuolumeni, \\ Port Harcourt, Rivers State, Nigeria. \\ Email: owowisdom70@ @otmail.com, Tel: +234 (0) 8035434770. \\ Gogo J. Owo \\ Department of Biochemistry, Faculty of Science, Federal University Otuoke, \\ Bayelsa State, Nigeria. \\ Email: Gogojames76@gmail.com
}

DOI: $10.31364 / \mathrm{SCIRJ} / \mathrm{v} 7.11 .2019 . P 0119605$

http://dx.doi.org/10.31364/SCIRJ/v7.i1.2019.P0119605

\begin{abstract}
Poor academic performance may be caused by many factors not excluding exposure to cyanides in cassava products which may result in mental retardation, poor cognitive function, memory loss, neurological disorders and visual impairments. Cyanogenic potentials in garri flour from four Areas in Rivers State, Nigeria were determined. The cyanogenic potentials of the garri samples determined ranged from 14.51 to $21.00 \mathrm{ppm}$ and were above the FAO/WHO recommended safe level of $10 \mathrm{ppm}$. Communities in Area 4 produced garri flour with high cyanogenic potential of $21.00 \mathrm{ppm}$ while those in Area 3 produced garri flour with low cyanogenic potential of $14.51 \mathrm{ppm}$. The results revealed the risk of developing problems like depression, poor cognitive function and congenital malformations due to cyanide poisoning that may possibly lead to poor academic performance among students in all the sampled Areas with Area 4 having higher possibilities compared to other Areas. And so, it was recommended that the Ministry of Health and the Ministry of Education should collaborate to sensitize and educate the parents and students/pupils on the health disorders associated with cyanide. Also, parents should prevent children below 16years from excessive intake of garri to minimize the risks of cyanide poisoning on their memory, cognitive function and attention which may lead to poor academic performance.
\end{abstract}

Keywords: Cyanogenic glycosides, Manihot esculenta crantz, toxicity, poor academic performance, disorders.

\subsection{Introduction}

Cassava (Manihot esculenta crantz) is an essential food crop mostly consumed by people in the tropical regions of Africa (30) and it is the most widely cultivated specie of the genus manihot (2). There are two types of cassava: Sweet cassava (Manihot esculenta) and Bitter cassava (Manihot utilisssima). The bitter cassava has high level of cyanogenic glycosides than the sweet cassava $(1,17)$. Cyanogenic glycosides are natural toxicants in foods (mostly in cassava roots and leaves) that produce hydrocyanic acid (hydrogen cyanide) on hydrolysis $(11,12)$.

Two common cyanogenic glycosides present in cassava are linamarin and lotaustralin (12). Linamarin is found in high concentration than lotaustralin $(18,12)$. Linamarin produces glucose and acetone cyanohydrin on hydrolysis by the action of the enzyme linamarase, and the acetone cyanohydrin further undergoes alkaline or acidic degradation to form the toxic hydrogen cyanide $(4,11,12,24,30)$.

It was reported that garri flour is the most widely consumed cassava product (7). There are two forms of garri flour produced in Nigeria: white and yellow garri flour. The yellow garri flour is formed when palm oil is added to the graded pulp before or after dewatering and fermentation process and then fried (25).

In Rivers State, South-south Nigeria, cassava root is mostly consumed in different forms such as garri flour (eba), akpu (loiloi), tapioca and cassava porridge (22). Garri flour is mostly consumed as eba (baked with hot water) with soup, or eaten as snacks (either mixed with palm oil or soaked in water) 
sweetened with sugar and milk or salt and also consumed in combination with dried fish, coconut, kernel nuts, groundnuts or cooked beans $(25,33)$. This practice is common among students in various institutions in Nigeria.

The cyanogenic potential of the garri flour samples is the sum of the concentration of hydrogen cyanide, $\mathrm{HCN}$ equivalent of linamarin, acetone cyanohydrin and cyanide ion present in the garri flour to be analysed $(11,19)$.

The WHO recommended safe level of cyanogenic potential (total cyanogens) in garri flour (Cassava flour) is $10 \mathrm{ppm}(13,29)$. Previous researches on garri flour found in local markets and communities in Nigeria have shown that there is high concentration of cyanogens above the WHO acceptable safe level of 10 ppm for garri flour $(10,22,25,29)$.

There are various health disorders associated with both acute and chronic cyanide toxicity leading to cyanide poisoning $(8,22)$ due to poor processing of cassava products. Cyanide accumulation in the body system causes the inhibition of cytochrome c oxidase and hence prevents the proper utilization of oxygen leading to a condition known as cytotoxic anoxia (9). Acute cyanide toxicity has been found to cause increased breathing rate, restlessness, salivation, nerve lesions, nausea, anxiety, central nervous system (CNS) depression, hypotension, tropical ataxic neuropathy, respiratory failure, tremors, convulsions, mental confusions and death $(21,32)$.

On the other hand, chronic cyanide toxicity leads to malnutrition, diabetes, congenital malformations, neurological disorders and myopathy (14). Tropical ataxic neuropathy, a common disorder due to cyanide poisoning, leads to several problems like loss of hand sensations, jerking, visual impairments, deafness and weakness $(5,6)$.

Education is an important tool for any development in every growing country of the world, and Nigeria is not an exception. Globally, poor academic performance of students is one of the major problems the families, society and government and other stakeholders in education do not like to experience.
Academic performance may be referred to as the outcome or product of the extent to which students, learners or teachers have achieved their academic aims and is usually measured by examinations, continuous assessment and skills (34). Many health or psychological disorders may contribute to poor academic performance among students and some of the disorders are anxiety, loss of memory, congenital malformation of the brain, depression, visual impairment and so on $(15,23)$.

The effect of cyanides on motor activity was also observed during acute cyanide toxicity phase and was more pronounced in the CNS (20).

According to (7) depression leads to impairment of cognitive functioning and hinders academic performance. Depression affects and impairs memory capacity among adolescents who are mostly students (27). Depression also upset concentration and attention during learning and hence may possibly affect academic performance (3).

Cyanides have been demonstrated to stimulate and cause depression on the central nervous system (26), leading to poor or lower academic performance in young people (23). Hence the purpose of this study was to determine the concentration of cyanide in garri flour as well as discussing the implication of the level of cyanide with respect to pupils'/students' learning and academic performance.

\subsection{Research Questions (RQ)}

RQ 1: What is the mean concentration of cyanide in garri flour produced in each of the four areas (Emohua, Obio/Akpor, Etche, and Ogoni) under study?

RQ 2: Are the mean concentration of cyanide in garri flour produced in each of these areas falls within FAO/WHO permissible or safe limits?

\subsection{Materials and Methods}

\subsection{Sampling and Sampling Area}


Rivers State was divided into 4 areas namely Emohua area (Area 1), Obio/Akpor area (Area 2), Etche area (Area 3) and Ogoni area (Area 4) to ensure that adequately representative sampling was carried out. Initial survey was carried out to detect the three major communities producing garri flour in each area. In each area, garri flour samples were collected at random from 3 garri flour producing communities in Rivers State and mixed together to obtain Area representative sample and analysed properly.

Table 1: Sampling Areas

\begin{tabular}{|c|c|l|}
\hline Area & Area name & \multicolumn{1}{|l|}{ Selected Local markets } \\
\hline 1 & Emohua & $\begin{array}{l}\text { Ndele, Emohua and } \\
\text { Elele }\end{array}$ \\
\hline 2 & Obio/Akpor & $\begin{array}{l}\text { Rumuolumeni, Choba } \\
\text { and Rukpoku }\end{array}$ \\
\hline 3 & Etche & $\begin{array}{l}\text { Ulakwo, Okehi and } \\
\text { Igbodo }\end{array}$ \\
\hline 4 & Ogoni & Kaa, Nonwa and k-Dere \\
\hline
\end{tabular}

\subsection{Determination of Cyanogenic Potentials}

Evaluation of cyanogenic potential was carried out using the principle of semi-qualitative elution of the picric acid paper and spectrophotometric analysis as described by Ikediobi, Onyika \& Eluwah and Edwards \& Williams (7, 31). The Bausch and Lombe 20 Spectronic spectrophotometer was used to measure the absorbance of the $\mathrm{HCN}$ reacted picrated paper against blank at $515 \mathrm{~nm}$. The absorbance was multiplied by 396 to obtain the total cyanogen content (cyanogenic potential) in ppm.

\subsection{Statistical analysis}

The statistical analysis of data was done using Standard Statistical Package SPSS 21.0. Mean and Standard Error of Mean (SEM) were used for analysis of data. Each result is a mean of triplicate analysis and compared to the WHO recommended safe level of cyanogenic potential $(10 \mathrm{ppm})$ for garri flour.

\subsection{Results and Discussion}

The mean values for the cyanide potential of the test samples from the four areas is presented in Table 2.

From the results in Table 2 and fig. 1, the mean cyanide potential of garri flour produced in all the four areas were much above the WHO recommended safe level for garri flour (10 ppm or $10 \mathrm{mg}$ $\mathrm{HCN}$ equivalent/Kg dry weight). And so, substantiates results of previous studies by $(10,22,25)$. The high cyanide potential in garri flour in these Areas indicates that consumers of garri in these communities are more likely to experience cyanide poisoning. However, the garri flour produced in Area 4 had the highest cyanogenic potential $(21.00 \mathrm{ppm})$ while that of Area 3 had the lowest cyanogenic potential (14.51ppm). This implies that the communities in area 3 produced garri flour with reduced risk of cyanide poisoning than other Areas. Local consumers and students in this area will be prone to lower risk of cyanide due to moderate practices employed in the processing of garri flour and other cassava products. Whereas, consumers including students in the communities in Area 4 are most likely to be exposed to high risk of cyanide poisoning due to high cyanide content of garri flour produced in this area.

Cyanides have been reported to have the ability to block mitochondrial oxidative phosphorylation and can also interfere with enzyme and specific organ activities (25). Cyanide inhibits cytochrome c oxidase and hence prevents the proper utilization of oxygen leading to a condition known as cytotoxic anoxia (9).

These inhibitory roles of cyanide may result in various disorders such as hepatic encephalopathy, CNS depression and chronic hypoxia (16) which are involved in loss of attention, poor cognitive function and loss of memory.

Higher levels of anxiety and depression are two psychological problems that have been linked to reduce academic performance in young people (23). Depression has a high occurrence and relationship with both memory and poor academic performance.

It is however possible that cognition deficits may be associated with high level of cyanides in garri flour and other cassava products consumed leading to poor academic performance. 
Table 2. Cyanogenic potential of garri flour sample produced in local markets in Rivers State.

\begin{tabular}{|l|l|l|l|}
\hline Area & Mean \pm SEM & Minimum & Maximum \\
\hline 1 & $15.58 \pm 1.93$ & 8.23 & 23.50 \\
\hline 2 & $18.24 \pm 1.33$ & 14.80 & 24.50 \\
\hline 3 & $14.51 \pm 0.74$ & 12.50 & 18.00 \\
\hline 4 & $21.00 \pm 0.78$ & 14.80 & 25.00 \\
\hline
\end{tabular}

The values are presented as mean \pm standard error of mean of three replicate analysis

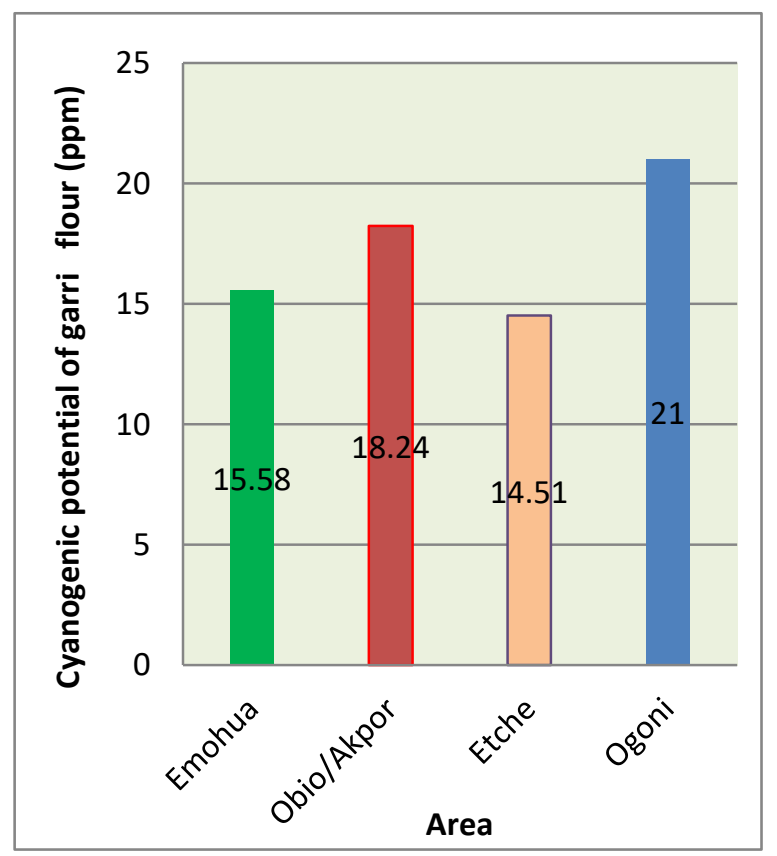

Fig.1: Areas of cyanogenic potential (ppm)

The observed higher cyanogenic potential in area 4 (See figure 1) compared to other areas revealed that poor garri flour processing techniques were employed (22) and this may induce some effects on the academic performance of students due to loss of attention, depression, anxiety, poor cognitive function and loss of memory (23).

\subsection{Conclusion}

This study reveals the cyanogenic potential levels for garri flour produced in some areas in Rivers State and its effects on academic performance of students.

The cyanogenic potential levels for garri flour produced in the four areas studied ranged from 14.51 to $21.00 \mathrm{ppm}$ which is relatively above the acceptable limit of $10 \mathrm{ppm}$ and may induce some effects of toxicity on humans. Some of the effects are tropical ataxic neuropathy, goitre, mental problems, cretinism, encephalopathy, brain and optic nerve degeneration and cardiac problems $(5,12,14)$.

Among the areas studied, Area 4 has the highest cyanogenic potential of $21.00 \mathrm{ppm}$ while Area 3 has the lowest cyanogenic potential of $14.51 \mathrm{ppm}$. The relatively low cyanogenic value in garri flour in Area 3 indicates that garri flour in this Area 3 is possibly produced based on the traditional methods of peeling and grating, dewatering and fermentation for 3 days to reduce the concentration of cyanides in garri flour to less toxic level that may be considered safe for consumption (19).The reason for the variation in the cyanogenic potentials of garri flour produced in these areas may be due to differences in processing and storage techniques employed in these areas. Another reason may be due to the exposure of the garri flour to some pollutants containing cyanide.

\subsection{Educational implications}

The effects of cyanide on cognitive function, memory, learning and hence academic performance have been documented in literature. Findings from this study have shown that the concentration of cyanide in garri flour is higher than the FAO/ WHO recommended level for cyanide in food and therefore implied that consumption of garri flour is one of the many sources in which cyanide gets into humans body to create health and mental or cognitive disorders such as hepatic encephalopathy, CNS depression and chronic hypoxia, inhibition or retardation of cognitive functions which can translate into loss of memory, poor learning and poor academic achievement.

\subsection{Recommendations}


As a result of the effect of cyanide on the central nervous system and mental health, we therefore call on the Ministry of Health and the Ministry of Education to sensitize and educate the public especially parents and students/pupils on the health disorders associated with cyanide. Again, parents should prevent their children who are below 16years from excessive intake of garri to minimise the risks of cyanide poisoning on their memory, cognitive function and attention which may lead to poor academic performance.

More so, government agencies such as National Agency for Food and Drug Administration Control (NAFDAC) and Agricultural Development Programme (ADP) should organise lectures, symposia or seminars to educate local cassava processors, parents and retailers on the methods of processing and storing cassava products.

\section{References}

1)

A. Akintonwa and O. Tunwashe, "Fatal cyanide

poisoning from cassava-based meal".

Human and Experimental Toxicology, 11, pp. 47-

49.1992 .

2) A. Alves, "Cassava botany and physiology. In:

Cassava: Biology, Production and Utilization. R.J. Hillocks, J.M. Thresh and A.C. Bellotti (eds).2000.

3) A. O. Busari and M.S. Eniola, "The Effects of Therapeutic Management Approach on Depressive Symptomatology and Cognitive Task Performance among the Physically Challenged Students of Rehabilitation Centre, Ibadan, Nigeria”. The Anthropologist: Int. J. Contemporary and Applied Studies on Man. 10(1): 25 -30, 2008.

4) A. S.A. Oluwale, A.O. Onabolu., I.A. Cotgreave., H. Rosling., A. Parson., and H. Link. "Incidence of endemic ataxic polyneuropahthy and its relation to exposure to cyanide in a Nigerian community". $J$. Neurol. Neurosurg. Psycho., Vol. 74, pp. 1417-1422, 2003.

5) B. Osuntokun, "Cassava diet, chronic cyanide intoxication and neuropathy in Nigerian Africans".
World Review of Nutrition and Dietetics, Vol.36, pp. 141-173, 1981 .

6) B. Osuntokun, "Chronic cyanide intoxication of dietary origin and a degenerative neuropathy in Nigerians". Acta Horticulturae, Vol.75, pp. 311-321, 1994.

7) C. O. Ikediobi, G.O.C. Onyika and C.E. Eluwah, "A rapid and inexpensive assay for total cyanide in cassava and cassava products". Agric. Biol. Chem., 44: 2803$2809,1980$.

8) D. L. Dufour, "Assessing diets in population at risk for konzo and neurolathyrism".Food Chem. Toxicol. 49:655-661, 2011.

9) D. Rorison and S. McPherson,"Acute Toxic Inhalations". Environmental Emergencies,

Vol.10, no.2, pp.409-35, 1992.

10) E. A. Komolafe and A.O. Arawande, "Quality characteristics of garri produced in some selected cassava processing centers in Owo, Ondo State, Nigeria”. J. Res. Nat. Dev. Vol. 8, no.1,pp. 23, 2011.

11) E. R. Jansz and I. Uluwaduge, "Biochemical aspects of cassava (Manihot esculenta Crantz)

with special emphasis on cyanogenic glycosides - A Review". J. Nat. Sci. Foundation. Sri Lanka Vol. 25, no.1, pp.1-24, 2012.

12) F. W. Mburu, S. Swaleh, and W. Njue, "Potential toxic levels of cyanide in cassava (Manihot esculenta Crantz) grown in Kenya". Afr. J. Food Sci.Vol. 6, no.16, pp.416 - 420, 2012.

13) FAO/WHO, "Joint FAO/WHO Food Standard Programme". Codex Alimentarius Commission XII, Supplement 4, Rome, FAO, Italy, 1991

14) FSANZ, "Final assessment report proposal P257. Advice on the preparation of cassava and bamboo shoots”. Report Number 2-04. Canberra: FSANZ, 2004.

H. D.Ande Decker., F. Raes and P. Eelen, "Autobiographical memory specificity and trauma in inpatient adolescents. J. Clin. Child andAdolescent Psychol., 32, pp.22-31. 2003. 
16) J. A. Hamel, "A review of acute cyanide poisoning with a treatment update". Critical care Nurse, Vol.31 no.1, pp.72-82, 2011.

17) J. Cock, "Cassava. New Potential for a neglected crop". Westview Press/Boulder, London, pp. 191, 1985.

J. H. Bradbury and I. C. Denton, "Simple method to reduce cyanogens content of garri made from cassava". Food Chem. Toxicol. Vol.123, no.3, pp 840 -845, 2010.

J. H. Bradbury, "Simple wetting method to reduce cyanogens content of cassava flour". J. Food Comp. Anal. Vol.19, no.4, pp. 388-393, 2006.

20) J. Hariharakrishnan, R. M. Satpute, and R. Bhattacharya, "Cyanide-induced changes in the levels of neurotransmitters in discrete brain regions of rats and their response to oral treatment with alphaketoglutarate." Indian Journal of Experimental Biology. Vol. 48 no.7, pp.731-736, 2010.

21) J. Rachinger F. A. Fellner, K. Stieglbauer and J. Trankler, "Epidemiological changes after acute cyanide intoxication". Am. J. Neuroradiol. Vol.23, pp.13981401, 2002.

22) M. N. Adindu and A. B. I, "Aprioku. Cyanogenic content of garri from some processing centers in River State, Nigeria". Nig. Food J. Vol.24, no.1, pp.135- 138, 2006.

23) M. Owens, J. Stevenson, J. Hadwin and R. Norgate, "Anxiety and depression in academic

performance: An exploration of the mediating factors of worry and memory'. School Psychology International, Vol.33, no.4, pp.34-46, 2012.

24) N. Okafor and A.O. Ejiofor, "Rapid detoxification of cassava fermenting for garri production following inoculation with yeast simultaneously producing Linamarase and Amylase". Proc. Biochem. Int., Vol.25, pp.82-86, 1990.

O. S. Ossai, "Total cyanogen content of garri flour produced in Delta State, Nigeria: Potential health risk". Adv. J. Food Sci. Technol., Vol.5, no.3: 244-248, 2013.
R. C. Gupta, "Handbook of Toxicology of Chemical Warfare Agents". Oxford, UK: Academic Press, pp.1168, 2009.

R. J. Park, I. M. Goodyear, and J.D. Teasdale, "Categorical over-general autobiographical memory in adolescents with major depressive disorder'. Cambridge:Cambridge University Press, pp. 32, 2002.

S. A. Frojd, E. S. Nissinen, M. U. I. Pelkonen, M. J. Marttuenb, and A. M. Koivisto, "Depression and school performance in middle adolescent boys and girls. J. Adolescence, 31, pp. 485-498, $2008 . \quad$ DOI: 10.1016/j.adolescence.2007.08.006.

S. A. Odoemelam, "Studies on the residual hydrocyanic acid (HCN) in garri flour made from cassava (Manihot spp.)". Pak. J. Nut. Vol.4, no.6, pp.376- 378, 2005.

S. H. Katz and W. W. Weaver, "Encyclopedia of Food and Culture". New York: Schribner, New York, NY USA, 2003.

T. G. Edwards and H. J. Williams "Estimation of cyanide with alkaline picrate". J.Sci. Food Agri., 31, pp. 15-22, 1980.

U.S. E.P.A, "Reviews of the Environmental Effects of Pollutants: V. Cyanide, prepared for the Office of Research and Development" ORNL/EIS-81, EPA600/1-78-027, 1978.

UNICEF/IITA, "In Praise of Cassava. UNICEF/ IITA household food security and Nutrition Program". International Institute of Tropical Agriculture, Ibadan, pp: 229, 1989.

W. Annie, W. S. Howard, and M. Mildred, "Achievement and Ability Tests - Definition of the Domain, Educational Measurement". University Press of America, pp, 2-5, 1996. ISBN 978-0-76180385-0. 
